\title{
"Providing constructive interaction of subjects of labor relations based on social dialogue and social responsibility"
}

\author{
Oksana Pankova (D https://orcid.org/0000-0002-2003-8415 \\ R http://www.researcherid.com/rid/Q-1881-2018 \\ AUTHORS \\ Oleksandr Kasperovych (D) https://orcid.org/0000-0003-1169-9681 \\ Oleksandr Ishchenko (D) https://orcid.org/0000-0003-0307-557X \\ R http:/www.researcherid.com/rid/C-1084-2018
}

ARTICLE INFO

Oksana Pankova, Oleksandr Kasperovych and Oleksandr Ishchenko (2019).

Providing constructive interaction of subjects of labor relations based on social dialogue and social responsibility. Social and labour relations: theory and practice, 9(1), 14-26. doi:10.21511/slrtp.9(1).2019.02

DOI http://dx.doi.org/10.21511/sIrtp.9(1).2019.02

RELEASED ON

Tuesday, 16 July 2019

RECEIVED ON

Sunday, 10 March 2019

ACCEPTED ON

Friday, 24 May 2019

\section{(c)) EY}

LICENSE

This work is licensed under a Creative Commons Attribution 4.0 International License

JOURNAL

"Social and labour relations: theory and practice"

ISSN PRINT

$2410-4752$

ISSN ONLINE

2415-3389

PUBLISHER

LLC "Consulting Publishing Company "Business Perspectives"

FOUNDER

State Higher Educational Establishment "Kyiv National Economic University named after Vadym Hetman", Social and Labour Relations Institute

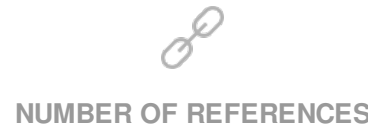

28
NUMBER OF FIGURES

0

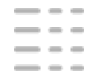

NUMBER OF TABLES

0

(C) The author(s) 2023. This publication is an open access article. 


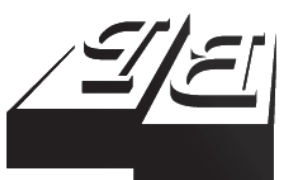

BUSINESS PERSPECTIVES

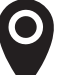

Publisher

LLC "CPC "Business Perspectives" Hryhorii Skovoroda lane, 10, Sumy, 40022, Ukraine www.businessperspectives.org

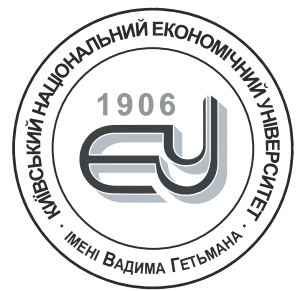

\section{HETMAN KNEU}

Founder

State Higher Educational

Establishment "Kyiv National

Economic University named after

Vadym Hetman",

Prospect Peremogy, 54/1,

Kyiv, 03057, Ukraine

https://kneu.edu.ua/

Received on: 10th of March, 2019 Accepted on: 24th of May, 2019

(c) Oksana Pankova,

Oleksandr Kasperovych,

Oleksandr Ishchenko, 2019

Oksana Pankova, Ph.D. in Sociology, Associate Professor, Sociology Department, Kyiv National Economic University named after Vadym Hetman, Ukraine.

Oleksandr Kasperovych, Chief Economist, Economic Problems of Social Policy Department, Institute of Industrial Economics of NAS of Ukraine, Ukraine.

Oleksandr Ishchenko, Senior Economist, Economic Problems of Social Policy Department, Institute of Industrial Economics of NAS of Ukraine, Ukraine.

\section{(c) (i)}

This is an Open Access article, distributed under the terms of the Creative Commons Attribution 4.0 International license, which permits unrestricted re-use, distribution, and reproduction in any medium, provided the original work is properly cited.
Oksana Pankova (Ukraine), Oleksandr Kasperovych (Ukraine), Oleksandr Ishchenko (Ukraine)

\section{PROVIDING CONSTRUCTIVE} INTERACTION OF SUBJECTS OF LABOR RELATIONS BASED ON SOCIAL DIALOGUE AND SOCIAL RESPONSIBILITY

\begin{abstract}
The article presents the results of research on the interaction of subjects of social-labor relations on the basis of assessment of the state and dynamics of the main factors influencing it (on the basis of sociological studies and other data). The state and main problems of development of key subjects trade unions and employers' associations are analyzed, the main factors that negatively influence their activity are determined. The basic scheme used for analysis of the main social factors that determine the interaction of subjects of social and labor relations is the conceptual triad "trust - awareness motivation". The conditions of activating the constructive interaction of subjects of social and labor relations in the context of the principles of social responsibility and social dialogue are determined. The main ones are increasing mutual trust, creating an effective communication system, as well as having the will to reconcile interests and readiness for dialogue and compromise. The basic requirements to the modern informational-communicative strategy of interaction of subjects of social-labor relations are substantiated. In particular, they include the following: implementation of the principles of social dialogue and social responsibility; orientation on the possibilities of modern information and communication technologies; orientation on the solution of the most acute problems in the field of social-labor relations; creation of effective mechanisms of feedback between communication actors. Basing on the results of the analysis, the directions and conditions for the activation of constructive interaction between the participants of the social dialogue are proposed and substantiated, in the context of the state and dynamics of key social and socio-psychological factors.
\end{abstract}

Keywords

JEL Classification labor relations, constructive interaction, social dialogue, social responsibility, trust, conventional communicative strategy

J5, M14
О.В Панькова (Україна), О.Ю Касперович (Україна),

О.В Іщенко (Україна)

\section{ЗАБЕЗПЕЧЕННЯ КОНСТРУКТИВНОЇ ВЗАЄМОДІЇ СУБ'ЄКТІВ СОЦІАЛЬНО- ТРУДОВИХ ВІДНОСИН НА ЗАСАДАХ СОЦІАЛЬНОГО ДІАЛОГУ ТА СОЦІАЛЬНОЇ ВІДПОВІДАЛЬНОСТІ}

\begin{abstract}
Анотація
У статті представлено результати дослідження проблем взаємодії суб'єктів соціально-трудових відносин (СТВ) на основі оцінки стану та динаміки змін основних чинників, що впливають на неї (на основі соціологічних досліджень та інших даних). Проаналізовано стан та основні проблеми діяльності ключових суб'єктів - профспілок та об’єднань роботодавців, визначено основні чинники, що негативно впливають на їх розвиток. Як основні соціальні чинники, що визначають взаємодію суб’єктів соціально-трудових відносин, використано концептуальну тріаду «довіра - поінформованість - вмотивованість». Визначено умови активізації конструктивної взаємодії суб'єктів соціально-трудових відносин в контексті принципів соціальної відповідальності та соціального діалогу, основними з яких $є$ підвищення взаємної довіри, створення ефективної системи комунікації, а також наявність волі до узгодження інтересів і готовність до діалогу та компромісу кожного з суб’єктів СТВ. Обгрунтовано
\end{abstract}


основні вимоги до сучасної інформаційно-комунікативної стратегії взаємодії суб'єктів соціально-трудових відносин, якими, зокрема, є такі: реалізація принципів соціального діалогу та соціальної відповідальності; орієнтація на можливості сучасних інформаційно-комунікативних технологій; приорітетність вирішення найбільш гострих проблем в сфері соціально-трудових відносин; створення дієвих механізмів зворотного зв'язку між суб’єктами комунікації. За результатами проведеного аналізу запропоновано та обгрунтовано напрями та умови активізації конструктивної взаємодії сторін соціального діалогу з урахуванням стану та динаміки змін ключових соціальних та соціально-психологічних чинників.

\section{Ключові слова}

Класифікація JEL соціально-трудові відносини (СТВ), суб’єкти СТВ, конструктивна взаємодія, соціальний діалог, соціальна відповідальність, довіра, комунікативна стратегія

J5, M14

\section{ВСТУП}

Докорінне реформування системи суспільних і соціально-трудових відносин в Україні на засадах соціального діалогу та соціальної відповідальності є необхідною умовою виходу України 3 глибокої соціально-економічної кризи, подолання внутрішньополітичної та зовнішньополітичної нестабільності, зняття гострих протиріч в сфері праці й переходу на траєкторію сталого збалансованого зростання. Для цього необхідно максимально мобілізувати відповідні внутрішні ресурси і резерви. Важливим нематеріальним ресурсом, який здатен забезпечити успішність економічних та соціальних реформ, високу конкурентоспроможність економіки, покращення якості трудового і соціального життя, удосконалення виробничих відносин, виступає конструктивна співпраця між суб'єктами соціальнотрудових відносин (далі - СТВ): між працівниками, владою та бізнесом на базі розширеної платформи публічного діалогу (соціального діалогу), соціально відповідального партнерства. Соціальний діалог забезпечує участь роботодавців і працівників у розробці і реалізації соціально-трудової та соціальноекономічної політики і відіграє роль унікального інструменту забезпечення балансу інтересів найманих робітників, підприємців і влади на користь усього суспільства. Така платформа дозволяє інтегрувати в управлінські рішення передовий досвід збалансування приватних та суспільних інтересів на шляху підвищення конкурентоспроможності національної економіки, сприяє реалізації основних цілей сталого розвитку для України: справедливого соціального розвитку; сталого економічного зростання та продуктивної зайнятості; ефективного управління; захисту трудових прав та забезпечення безпечних умов праці для всіх працюючих тощо [13].

\section{1. ЛІТЕРАТУРНИЙ ОГЛЯА}

У науковій літературі зазначається, що соціально-трудові відносини завжди містять компонент суперечностей, оскільки інтереси сторін і суб'єктів цих відносин, якщо не протилежні, то щонайменше далеко не однакові. Природа означених суперечностей полягає в необхідності одночасного досягнення стандартів гідної праці, соціальної справедливості, стійкої позитивної соціальної динаміки, з одного боку, та підвищення економічної ефективності, реалізації інтересів власників капіталу - 3 іншого [11]. Пошуку способів та механізмів розв'язання цієї проблеми, досягнення балансу інтересів сторін СТВ, модернізації системи СТВ в Україні через соціальний діалог та соціальну відповідальність присвячено багато наукових праць вітчизняних економістів, соціологів, правознавців, спеціалістів 3 державного управління, зокрема Антонюк, Арсеєнка, Близнюк, Герасименко, Гетьманцевої, Грішнової, Колота, Лібанової, Новікової, Петрової, Петроє, Пилипенка, Чепурко, Шастун та інших.

Провідний український фахівець з проблем трудових відносин Колот зазначає, що на основі соціального діалогу досягається формальна чи неформальна, гласна чи негласна домовленість між його сторонами про взаємні зобов'язання. Реалізація цих домовленостей сторонами діалогу створює платформи для взаємодопомоги, обміну суспільно значущими послугами, для формування гарантій та створення додаткових можливостей у реалізації як власних, так і спільних інтересів. Такі платформи дозволяють консолідовано досягати узгодженої економічної, соціальної й екологічної динаміки розвитку, протистояти новим викликам та загрозам, пов'язаними з глобалізацією - гальмувати темпи галопуючої соціальної нерівності, знижувати дефіцит гідної праці, зменшувати прошарок прекаріату тощо [10, с. 9-10]. Сучасні негативні тенденції у сфері СТВ, які «вимивають» кваліфіковану робочу силу національної економіки, 
перешкоджають розвитку людського капіталу (ЛК) і трудового потенціалу України, розкриває також Антонюк [1].

Дослідження, проведені Новіковою та Шастун, показали, що вагомим внутрішнім чинником посилення ризиків у сфері праці в Україні виступають знецінення праці, непрестижність трудових цінностей, безвідповідальність і роботодавців, і працівників, і державних органів та структур влади. Мінімізація цих загроз можлива за умови якісних змін в суспільній свідомості, що проявлятиметься у реалізації соціально-відповідальної поведінки кожного суб’єкта СТВ на засадах конструктивного соціального партнерства $[15 ; 16]$.

У Аналітичній доповіді до щорічного Послання Президента України до Верховної Ради України «Про внутрішнє та зовнішнє становище України в 2018 році» визнається, що «у сфері трудових відносин досі не вдалося: активізувати соціальний діалог і перетворити його в повноцінний інститут колективнодоговірного регулювання; принципово змінити трудове законодавство, виконати зобов'язання Угоди про асоціацію між Україною та ЄС щодо розширення та удосконалення соціального захисту у сфері зайнятості, збалансовано розв’язати суперечності децентралізації регулювання у сфері праці, розподілення соціальних зобов'язань та необхідних для їх виконання гілок та рівнів влади» [14, с. 223224]. При цьому український соціолог Арсеєнко, зазначає, що з переходом на капіталістичну систему господарювання, більшість працюючих українців опинилися в стані підневільних найманих робітників на службі у держави та необуржуазії, посилилися процеси експлуатації та відчуження від результатів праці, від управління виробництвом, від участі робітників у розподілі його результатів [2, с. 214]. Щоб зупинити процеси масового збідніння населення, подолати загрози втрати та руйнування трудового потенціалу країни, в тому числі і через масштабну трудову міграцію населення, необхідно зосередити зусилля усіх суб’єктів СТВ на стабілізації суспільно-політичної та соціально-економічної ситуації в Україні; одночасно необхідно здійснювати модернізацію системи СТВ та розв'язувати гострі проблеми, які накопичилися в цій сфері [17].

Для уникнення гострих конфліктів з непередбачуваними наслідками, у тому числі трудових, Семикіна та Беляк пропонують впровадити якісні зміни у соціальну взаємодію держави, роботодавців, профспілок, громадських організацій на культурних засадах: «соціальний мир в Україні значною мірою визначатиметься здатністю соціальних партнерів вступати у діалог та досягати компромісів, керуючись цінностями прогресивної корпоративної культури» [23, с. 3].

Гетьманцева висловлює переконання, що вирішення багатьох проблем у сфері праці можливе в разі налагодження соціального діалогу між усіма суб'єктами СТВ на засадах соціальної відповідальності та соціального партнерства, адже «соціальне партнерство є системою, яка має чітко виражену соціальну орієнтацію, невіддільну від соціальної справедливості, і виступає як певний спосіб інтеграції інтересів різних суб'єктів трудових відносин» [9, с. 85].

Наразі в Україні на концептуальному рівні вирішується широке коло питань щодо інституціоналізації принципів соціального діалогу та соціальної відповідальності як в системі суспільних відносин, так і в системі СТВ. Проте на сьогодні бракує досліджень, які 6 поєднували аналіз змін в українському суспільстві (вплив обставин надзвичайного характеру, процесів реформування у різних сферах, а також інших аспектів, що виникли після Революції Гідності) з можливостями впровадження соціального діалогу, реалізації принципів соціальної відповідальності для виходу на шлях стабілізації та збалансованого розвитку. Важливим є визначення стану та динаміки змін в системі СТВ, чинників, що на них впливають, характеру взаємодії основних сторін тощо.

\section{META}

Метою статті є визначення проблем та перешкод в системі взаємодії суб’єктів СТВ в Україні та вироблення прийнятних механізмів забезпечення переходу до їх конструктивної взаємодії на засадах соціального діалогу та соціальної відповідальності. 


\section{3. РЕЗУЛЬТАТИ}

Модернізація системи СТВ в Україні на засадах соціального діалогу та соціальної відповідальності має здійснюватися на підгрунті вироблення і реалізації на практиці норм і практик консенсусноорієнтованої відповідальної діяльності кожної зі сторін СТВ, що сприятиме залученню і використанню їх потенціалу самоорганізації для забезпечення соціально-економічного розвитку країни, підвищенню конкурентоспроможності національної економіки. У цьому контексті актуалізується запит на посилення публічного та відкритого соціального діалогу між урядом, соціальними партнерами та громадським суспільством (зацікавленими інститутами громадянського суспільства, незалежними експертами та громадськими активістами на місцях) на усіх його рівнях щодо забезпечення продуктивності у розв’язанні найгостріших проблем в соціально-економічній сфері, в сфері суспільних відносин в цілому. Долучення до публічних комунікацій усіх зацікавлених сторін посилить взаємну довіру та соціальну відповідальність партнерів, дасть змогу опрацювати узгоджену усіма зацікавленими учасниками Дорожню карту «Стратегія модернізації соціального діалогу» [21], рекомендовану для впровадження учасниками круглого столу «Стан, виклики та ризики в царині соціального діалогу як чинника управління сталим розвитком країни». Розширений формат ефективного соціального партнерства між державними інституціями, приватним сектором і інститутами громадянського суспільства, спираючись на досвід і стратегії використання ресурсів партнерів, стає стратегічним орієнтиром інституційного забезпечення сталого розвитку в Україні (згідно прийнятого ООН Порядку денного сталого розвитку до 2030 р. при підтримці Міжнародної Організації Праці (МОП) [26]). Згадана вище Дорожня карта «Стратегія модернізації соціального діалогу» вимагає від усіх соціальних партнерів, насамперед бізнесу, бути соціально відповідальними, суспільство та влада повинні забезпечити соціальним партнерам (сторонам СТВ) можливість впливати на формування регуляторної, податкової, інвестиційної та соціальної політики.

Трансформація соціального партнерства на основі принципів соціальної відповідальності узгоджується з новою парадигмою розвитку соціального діалогу в Україні в контексті реалізації положень Угоди про Асоціацію Україна-ЄС на засадах взаємодії сторін - соціальних партнерів та представників третього сектору у форматі «соціальний діалог+» для збалансування економічних, соціальних та екологічних інтересів українського суспільства.

Основними суб'єктами розширеної платформи відповідального соціального партнерства на різних рівнях, виступають сторони СТВ. Вони ж виступають і суб’єктами забезпечення соціальної відповідальності у сфері праці [11]. До таких суб’єктів відносяться:

- роботодавці, які безпосередньо реалізують програми і заходи, що відповідають принципам соціальної відповідальності;

- наймані працівники та трудові колективи, які впливають на формування інституту соціальної відповідальності, висувають вимоги до соціально відповідальних дій з боку роботодавців і самі $є$ як об’єктами соціально відповідальних дій, так і суб’єктами соціально відповідальної поведінки;

- представницькі органи найманих працівників і роботодавців, інші інститути громадянського суспільства, які репрезентують інтереси відповідних суб’єктів, їх об’єднань, груп громадян; висувають вимоги до соціально відповідальної поведінки інститутів економіки та суспільства і самі $є$ суб'єктами соціально відповідальних дій;

- органи державної влади і місцевого самоврядування, які сприяють створенню конкурентних умов діяльності підприємств і реалізації ними норм і правил соціально відповідальної поведінки; а також ті, що забезпечують запобігання та мінімізацію наслідків соціально-трудової конфліктності в системі СТВ (зокрема, Національна служба посередництва і примирення);

- населення як об’єкт соціально відповідальної поведінки та джерело неформальних норм і правил у цій царині.

Таким чином, обидва суспільні інститути - інститут соціального партнерства та інститут соціальної відповідальності - є взаємопов’язаними і впливають на систему відносин в сфері праці. Якщо соціальне 
партнерство $€$ механізмом узгодження соціальних інтересів сторін, то соціальний діалог - інструментом реалізації такого механізму, через «визначення та зближення позицій, досягнення спільних домовленостей та прийняття узгоджених рішень сторонами соціального діалогу, які представляють інтереси працівників, роботодавців та органів виконавчої влади і органів місцевого самоврядування, 3 питань формування та реалізації державної соціальної та економічної політики, регулювання трудових, соціальних, економічних відносин» [25].

Згідно із положеннями Закону України «Про соціальний діалог в Україні», соціальний діалог здійснюється на національному, галузевому, територіальному та локальному (підприємство, установа, організація) рівнях на тристоронній або двосторонній основі і реалізується через обмін інформацією; консультації; узгоджувальні процедури; колективні переговори з укладення колективних договорів і угод, спільний пошук і прийняття домовленостей, спільних рішень у разі виникнення трудових конфліктів для термінового реагування [25].

На основі соціального діалогу досягається формальна чи неформальна, гласна чи негласна домовленість між його сторонами про взаємні зобов’язання. Реалізація цих зобов'язань формує платформу взаємовідповідальної солідарної взаємодії заради суспільного блага - забезпечення збалансованого розвитку. Водночас рівень розвитку соціального партнерства $є$ індикатором довіри, толерантності, солідарності партнерів, сповідуваних ними цінностей.

Реалізація сторонами СТВ взятих на себе зобов’язань демонструє рівень їхньої соціальної відповідальності, стабілізує систему СТВ, що, у свою чергу, дозволяє забезпечити налагодження конструктивної взаємодії суб'єктів соціальної відповідальності в системі СТВ на усіх рівнях, яка проявляється у таких аспектах взаємодії суб’єктів СТВ:

- сформованості прогресивних взаємоузгоджених уявлень щодо місії, мети, завдань та наслідків розвитку соціально-відповідальної взаємодії в системі СТВ в контексті забезпечення сталого розвитку;

- участі у розробці документів колективно-договірного регулювання та реалізації взятих на себе зобов’язань щодо соціального захисту, забезпечення безпеки та охорони праці, сталого соціальноекономічного розвитку тощо;

- залученні якнайширшого кола суб’єктів соціально відповідальної діяльності до розв’язання проблем CTB;

- зростанні потенціалу соціально відповідальних дій окремих суб'єктів зовнішнього і внутрішнього середовища підприємства чи галузі, поширення комунітарної (тобто спільної, солідарної, консолідованої) відповідальності;

- завчасному виявленні та попередженні загострення ситуації в системі СТВ на підприємствах, виникнення колективних трудових спорів, протестних акцій, проявів соціального невдоволення тощо.

Соціальна відповідальність у сфері праці є соціальним ресурсом суб’єктів СТВ, який сприяє забезпеченню балансу інтересів сторін шляхом соціального діалогу, досягнення цілей соціально-економічного і сталого розвитку, формування та реалізації конструктивних рішень у сфері СТВ [16]. Забезпечення соціальної відповідальності сторін соціального діалогу в трудовій сфері має здійснюватися:

- стороною роботодавців - через дотримання положень Кодексу законів про працю та інших нормативно-правових актів; дотримання положень колдоговорів, територіальних, галузевих угод, Генеральної угоди, правил трудової дисципліни і правил техніки безпеки; забезпечення умов для продуктивної праці, наповнення бюджетів усіх рівнів та фондів соціального захисту населення в межах укладених генеральних, галузевих, територіальних угод та колдоговорів для створення гідних умов праці для найманих працівників;

- профспілковою стороною - через виконання захисної функції, а саме: захист трудових і соціальноекономічних прав працівників, забезпечення гідної оплати, безпечних умов праці, дотримання соціальних стандартів, надання правової допомоги членам профспілок; 
- урядовою стороною (державними органами влади) - через регуляторно-правове забезпечення балансу інтересів усіх сторін соціального діалогу в системі соціально-трудових відносин на засадах розширеного відтворення бізнесу та кількості робочих місць; зміцнення соціально-економічної стабільності, законодавче та управлінське регулювання, забезпечення ефективності економіки, наповнення і виконання державного бюджету тощо.

Наявний стан трудової сфери в Україні, актуальні проблеми в системі СТВ є наслідком і проявом масштабної кризи в соціально-економічній та суспільно-політичних сферах, а труднощі їх подолання в значній мірі пов’язані із кризою довіри, посиленням нестабільності та зростанням напруженості в українському суспільстві. За даними всеукраїнських соціологічних досліджень [8], близько половини опитаних в Україні пов’язують зростання напруженості з дією саме економічних чинників: зростанням безробіття (48\%) та збідненням населення внаслідок зростання цін, підвищення тарифів (46\%), негативними оцінками діяльності влади. Важливими чинниками зростання напруженості, деструкції в системі суспільних відносин виступають корупція (44\%); безкарність та свавілля чиновників (41\%); недовіра до влади (34\%). Внутрішньополітичну кризу посилюють превалювання інтересів влади над інтересами держави і суспільства; поширення практики нехтування правами економічних агентів; використання владних повноважень для одержання надприбутків представниками крупного бізнесу; лобіювання інтересів господарських структур тощо [5]. Значний рівень недовіри в системі міжособистісних та міжгрупових відносин в Україні $\epsilon$ наслідком кумулятивної дії не лише економічних та політичних чинників, а ще й суто соціальних (низький рівень громадської активності та солідаризації суспільства, стомленість і розчарування рішеннями влади та наслідками реформ тощо) [24, с. 155]. Очевидно, що кризова соціально-економічна ситуація в країні негативно впливає на сферу соціальнотрудових відносин, на діяльність підприємств, на якість життя працюючого населення, перешкоджає конструктивній взаємодії суб’єктів СТВ.

Наразі основні зусилля щодо вирішення проблем в сфері СТВ спрямовуються на удосконалення нормативно-правової бази, запозичення передового досвіду розвинених країн (перш за все європейських), які здійснюються за широкої фінансової та організаційної підтримки міжнародних структур. Проте, фактично відсутні допоміжні механізми забезпечення конструктивної взаємодії суб'єктів СТВ в Україні, зокрема інформаційна база - не впроваджено моніторинг стану СТВ та динаміки їх змін. Хоча вітчизняними науковцями доволі широко досліджуються проблеми застосування моделей соціального діалогу та соціального партнерства в практиці управління, а також перешкоди, чинники та механізми їх реалізації. При цьому недостатньо уваги звертається на такі засадничі чинники соціальної взаємодії, як довіра, ідентичність, ментальність, здатність до соціальної, трудової та інноваційної активності, здатність реагувати на невизначеність та небезпеки тощо. В той же час, аналіз реального стану взаємодії суб’єктів СТВ потребує виокремлення та систематизації ключових чинників, що впливають на взаємодію. Це дозволить структурувати розрізнені дані соціологічних досліджень, які певною мірою дозволяють визначити механізми конструктивної взаємодії суб’єктів СТВ. 3 усієї сукупності чинників, з соціологічної точки зору, ключовою є тріада «довіра - поінформованість - вмотивованість»:

- взаємодія суб'єктів СТВ на виробничому рівні, у форматі довіра/недовіра, готовність вести діалог та сприймати одне одного як рівноправного партнера;

- взаємна поінформованість щодо реальної ситуації, проблем кожного з суб’єктів, наявність каналів прозорої та неупередженої інформаційно-комунікативної взаємодії, здатних мінімізувати різного роду маніпулятивні впливи;

- оцінка суб’єктами реальних можливостей захисту своїх інтересів та покращення ситуації саме шляхом діалогу, а не шляхом конфронтації та протестної активності;

- розвиток соціального діалогу між державою, владою, громадянським суспільством, бізнесом;

- забезпечення життєздатності біпартизму (двосторонньої системи соціального діалогу: роботодавець найманий працівник) на рівні підприємства/галузі. 
Суттєвою проблемою є тісне поєднання та взаємовплив всіх цих чинників, адже негативна динаміка будь-якого з них миттєво відображається на інших, створюючи в певному сенсі замкнене коло: недовіра закриває канали комунікації та блокує соціальний діалог, що призводить до непоінформованості і відсутності взаєморозуміння та оцінки реальної ситуації суб’єктів СТВ, в результаті оцінка перспективності діалогового вирішення протиріч знижується, проте зростає конфронтаційна складова взаємодії, недовіра підсилюється - і коло замикається.

В контексті наведеної вище тріади чинників «довіра - поінформованість - вмотивованість» в масовій свідомості населення України визначилися такі пріоритети довіри/недовіри суспільним інститутам. Так, за даними загальнонаціонального соціологічного дослідження, проведеного Центром ім. Разумкова ${ }^{1}, \mathrm{y}$ лютому 2019 р. довіра/недовіра до інститутів українського суспільства є такою: найчастіше громадяни України висловлюють довіру волонтерським організаціям (їм довіряють 67\% опитаних), 3бройним Силам України (62\%), Державній службі з надзвичайних ситуацій (61\%), Церкві (61\%). Недовіра найчастіше висловлюється державному апарату (чиновникам) (83\% населення України їм не довіряють), Верховній Раді України (не довіряють 82\%), судовій системі (78\%), політичним партіям (77\%), Уряду України (75\%), Президенту України (71\%), прокуратурі (70\%), Верховному Суду (65\%), Спеціалізованій антикорупційній прокуратурі та Національному антикорупційному бюро України (НАБУ) (65\%), профспілкам (58\%).

Наведені дані, а також результати інших досліджень свідчать, що в масовій свідомості населення України ставлення до профспілок як сторони соціального діалогу, яка покликана захищати колективні права та інтереси найманих працівників, є неоднозначним, суперечливим. Профспілки та їх об’єднання уособлюють самоорганізацію громадянського суспільства в трудовій сфері. Профспілки є громадськими об'єднаннями, представницькими органами найманих працівників, які покликані захищати їхні права та інтереси. Однак рівень довіри до профспілок з боку населення України залишається стабільно низьким. Так, ще у 2017 р. сумарний показник довіри становив 21.7\% (повністю довіряють + скоріше довіряють), а сумарний показник недовіри профспілкам був більш ніж вдвічі вищим - 50.3\% ${ }^{2}$, і лише 14\% опитаних було відомо про існування незалежних профспілок в Україні ${ }^{3}$. Наведені дані в цілому узгоджуються з результатами соціологічного моніторингу Інституту соціології НАН України і показує, що рівень недовіри профспілкам з року в рік зростає. Так, у 2016 році профспілкам зовсім та переважно не довіряли $45.9 \%$ опитаних, при цьому сумарний показник довіри (повністю довіряли чи переважно довіряли) становив 19.7\%. У 2018 році сумарний показник недовіри профспілкам з боку населення України становив 48.7\%, показник довіри знизився до 16.3\% при тому, що утруднювалися відповісти на питання вдвічі більша кількість опитаних - 34.4\% [27]. У 2019 році, як вже було сказано, не довіряло профспілкам 58\% населення України (довіряли лише 23.1\%). Отже, характерною рисою ставлення громадян країни до профспілок є тенденція посилення недовіри та невизначеності щодо оцінки їх діяльності [18]. Це виглядає дещо парадоксально, якщо врахувати той факт, що рівень юніонізації в Україні залишається високим (за даними опитувань - 78\%), що перевищує рівень охоплення профспілковим членством найманих робітників у багатьох західних країнах [2, с. 138-139]. Одночасно спостерігається стала тенденція до зменшення кількості первинних профспілкових організацій і профспілкового членства в Україні. Вітчизняні профспілкові організації, на відміну від зарубіжних, втратили вміння активно захищати права трудящих. Натомість вітчизняні профспілки віддають перевагу «бюрократичним іграм», кабінетній роботі. Реальністю української профспілкової практики є й те, що профспілкові лідери дедалі більше «вбудовуються» в провладні структури, представляючи інтереси не стільки найманих працівників, як парламентських партій та інших структур, що наближені до влади [11, с. 483]. Проте проблеми криються не лише в профспілках.

1 Загальнонаціональне дослідження «Рівень довіри до суспільних інститутів та електоральні орієнтації громадян України» проведене соціологічною службою Центру Разумкова з 7 по 14 лютого 2019 року в усіх регіонах України за винятком Криму та окупованих територій Донецької та Луганської областей. Опитано 2016 респондентів віком від 18 років. Теоретична похибка вибірки не перевищує 2.3\% [20].

2 Загальнонаціональне дослідження «Громадська думка, грудень-2017: виборчі рейтинги і рейтинги довіри» проведено Фондом «Демократичні ініціативи» імені Ілька Кучеріва спільно 3 соціологічною службою Центру Разумкова 315 по 19 грудня 2017 року в усіх регіонах України за винятком Криму та окупованих територій Донецької та Луганської областей. Опитано 2004 респондентів віком від 18 років. Теоретична похибка вибірки не перевищує 2.3\% [6].

3 Опитування громадської думки щодо громадянського залучення було проведено в серпні-вересні 2017 року Фондом «Демократичні ініціативи» імені Ілька Кучеріва. Опитано 2134 жителів України. Інтерв'ю були проведені 3 жителями України віком 18 років та старше. Вибірка $\epsilon$ репрезентативною для дорослого населення України за віком, статтю, областю та типом населеного пункту відповідно до даних Державної служби статистики України станом на 01.01.2016 (окрім АР Крим та непідконтрольних територій Донецької та Луганської областей). Максимальна теоретична похибка вибірки не перевищує 2.2\% (не включаючи дизайн-ефект вибірки) [7]. 
Серед основних причин наявного ставлення до профспілок з боку працівників і населення в цілому, можна зазначити такі:

- криза, погіршення стану економіки України через внутрішньополітичні та зовнішньополітичні потрясіння; загальна суспільно-політична нестабільність та невизначеність; низький рівень згуртованості та соціальної довіри у суспільстві в цілому;

- низька вартість робочої сили, зниження цінності людини праці, людини-виробника в державі;

- залежнапозиція профспілоктаїхлідерів відадміністрацій підприємств таїх власників, нерозвиненість лідерських якостей у керівників первинних профспілкових організацій;

- недостатня поінформованість працівників про діяльність профспілки, ії можливості як захисника їх соціально-трудових прав;

- обмеження значної частини профспілок у своїй діяльності традиційними функціями соціального захисту за рахунок профспілкових внесків працівників (надання матеріальної допомоги, сприяння відпочинку працівників тощо);

- впевненість значної частини працівників у безперспективності відстоювання своїх прав перед роботодавцем;

- небажання роботодавців (власників) додатково витрачати ресурси на гарантований соціальний захист працівників підприємств;

- нерозвиненість колективно-договірного регулювання на підприємствах приватної форми власності.

Наведені дані свідчать не просто про наявність певних проблем щодо сприйняття суспільством профспілок - вони свідчать про серйозну та стійку кризу довіри суспільства до них та вкрай низьку поінформованість щодо їхньої діяльності. Відсутність ефективної системи комунікації суб'єктів соціальної взаємодії в сфері СТВ тільки поглиблює цю кризу. Ця ситуація має цілком відчутні негативні наслідки - адже у випадку, коли довіра падає нижче критичного рівня, механізми суспільного управління і регулювання пробуксовують, здатність приймати та ухвалювати дієві управлінські рішення мінімізується [12, с. 108], що призводить до фактичної неможливості реалізації соціального діалогу. В цій ситуації важливим напрямом діяльності щодо відновлення довіри у суспільстві можуть стати, з одного боку, прозорість і послідовність політичних рішень, а з іншого - їх популяризація, пропагандистська активність у сполученні із зворотнім зв’язком політики і громадської думки [24, с. 156].

Іншим ключовим суб'єктом СТВ, чия діяльність має бути спрямована на налагодження конструктивної соціальної взаємодії з іншими суб’єктами, $є$ роботодавці та їхні об’єднання. Мотивація до самоорганізації роботодавців (і їх представників - об'єднань роботодавців) обумовлена, з одного боку, ступенем активності іншої сторони соціального діалогу (профспілок), яка, у свою чергу, багато в чому визначається традиціями самоорганізації працівників у певній галузі, а з іншого - економічним становищем галузі (суттєві проблеми або активне зростання стимулюють роботодавців до активізації взаємодії 3 профспілками для виправлення або покращення становища підприємств).

Дослідники визначають такі ключові фактори, що негативно впливають на процеси інституціоналізації сторони роботодавців в Україні та їхні можливості [3]:

1. Централізованість та суттєва політизованість процесів створення і діяльності об’єднань роботодавців у зв'язку із контролем представниками політичних сил провідних об'єднань роботодавців. Наслідком $є$ проблеми функціонування сторони роботодавців в рамках соціального діалогу, а також перешкоджання зростанню довіри як між інститутами сторони роботодавців, так і у їх відносинах з соціальними партнерами.

2. Низький рівень поінформованості та недостатнє усвідомлення підприємцями цілей створення та діяльності об'єднань роботодавців, сприйняття їхньої діяльності як такої, що спрямована перш за все захист прав та інтересів підприємців. Наслідком цього є, в тому числі, слабкість самоорганізаційних процесів у цій сфері, ставлення до об'єднань роботодавців з боку соціальних партнерів.

3. Невідповідність законодавства, що регулює діяльність об’єднань роботодавців, викликам сьогодення та проблема репрезентативності сторони роботодавців. 
4. Проблема створення та функціонування спільного представницького органу сторони роботодавців, в якому 6 приватні підприємці та малий бізнес мали $б$ реальні можливості представлення власних інтересів.

5. Несформованість представництва сторони роботодавців на рівні окремих галузей. Наслідком цього $\epsilon$ обмеження сфери соціального діалогу, пов’язаної із проведенням колективних переговорів та укладанням колективних угод у певних галузях економіки, оскільки відбувається часткова підміна сторони роботодавців урядовою стороною.

Наслідками негативних тенденцій розвитку сторони роботодавців в Україні є:

- низький, порівняно з країнами $Є С$, рівень самоорганізації підприємницького сектору в цілому та сторони роботодавців, зокрема;

- слабкі позиції сторони роботодавців у переговорах, насамперед із урядовою стороною (уряд часто ігнорує позицію бізнесу під час розгляду ключових для соціально-економічного розвитку країни документів (зокрема, бюджету), тим самим порушуються принципи рівноправності соціального діалогу та знижується мотивація бізнесу до участі в переговорному процесі);

- недостатня розвиненість колдоговірного регулювання на галузевому рівні;

- н низький рівень довіри увідносинахіз соціальнимипартнерами,щоспричиняєнизькурезультативність реалізації домовленостей;

- низькі можливості реалізації соціального діалогу з боку сторони роботодавців, перешкоди формуванню соціально відповідального бізнесу в країні.

В таких умовах зростає актуальність активізації позаекономічних чинників, включаючи норми соціальної відповідальності бізнесу (СВБ), корпоративної соціальної відповідальності (КСВ), корпоративної культури, процеси самоорганізації сторін соціального діалогу, спрямованих на оздоровлення і сприяння розвитку окремих підприємств, галузі та національної економіки в цілому. Однак активність у цій сфері реалізується переважно у проведенні масових заходів з акцентом на інтереси певної сторони соціального діалогу, в ході яких відбувається обговорення шляхів розв'язання проблем у сфері соціально-трудових відносин та соціального діалогу (прикладом можуть слугувати круглі столи, які регулярно проводяться в Україні, в тому числі за підтримки міжнародних організацій), але наслідком не стають реальні дії зацікавлених сторін. Тому назріла необхідність у дієвих заходах із розвитку соціального діалогу, виробленні норм і практики консенсусно-орієнтованої активної діяльності із захисту інтересів кожної $з$ сторін соціального діалогу, що сприятиме залученню і використанню їх потенціалу самоорганізації для забезпечення соціально-економічного розвитку на всіх рівнях.

Отже, аналіз показує, що значні проблеми існують не тільки в сфері забезпечення конструктивної взаємодії структур, які мають представляти та захищати інтереси робітників та роботодавців (тобто насамперед профспілок та об'єднань роботодавців), а і в становленні самих цих структур в якості реальних суб'єктів СТВ. Дані досліджень свідчать, що робітники слабо обізнані щодо діяльності профспілок та не довіряють їм, і так само роботодавці (особливо в сфері малого та середнього бізнесу) слабо обізнані щодо об’єнань роботодавців та в цілому не прагнуть долучатися до цих структур та брати активну участь в їхній діяльності.

Експерти стверджують, що діюча національна модель соціального діалогу не достатньо відповідає викликам часу та не виконує поставлені перед нею завдання. Причинами такої ситуації є, зокрема, його формальність в частині впливу сторони роботодавців та профспілкової сторони на прийняття управлінських рішень, зокрема щодо встановлення ключових соціально-економічних параметрів в сфері соціально-трудових відносин, що обумовлено застарілістю та неефективністю комунікаційного компоненту чинної моделі, зокрема на територіальному (місцевому) рівні. У цьому зв’язку, вкрай актуальним є посилення публічного та відкритого соціального діалогу між урядом, соціальними партнерами та громадським суспільством (зацікавлених ІГС, незалежних експертів, органів місцевої влади та громадських активістів на місцях) на усіх його рівнях щодо обговорення проблем та спільних дій в частині покращення його організації та управління. Сприяння долученню до публічних комунікацій 
усіх зацікавлених сторін посилить взаємну довіру та соціальну відповідальність партнерів, та дасть змогу опрацювати узгоджену усіма зацікавленими учасниками «дорожню карту» модернізації публічного та соціального діалогу, що дасть новий поштовх до якісної імплементації положень Глави ХХІ Угоди між Україною та ЄС в умовах децентралізації [22]. В цьому плані слушною є думка Гетьманцевої: «щоб соціальне партнерство перетворилося на ефективний механізм, необхідна побудова єдиного соціального простору, яка 6 передбачала універсальну систему соціального забезпечення, єдині соціальні стандарти, прийняття універсального соціального законодавства. Важливими $€$ на сьогодні не стільки проголошені принципи соціального партнерства, скільки механізми й форми їх втілення» $[9$, с. 86].

В контексті зазначеної вище тріади «довіра - поінформованість - вмотивованість» в якості одного 3 перших кроків у подоланні цієї ситуації має стати вирішення проблем у сфері інформаційнокомунікативної взаємодії - адже саме прозора та чесна комунікація $є$ необхідною умовою відновлення довіри суб'єктів СТВ одне до одного та відновлення соціального діалогу. Дієвим механізмом вирішення проблем у цій сфері може стати розробка та реалізація відповідної інформаційно-комунікативної стратегії, спрямованої на згуртування та збалансування інтересів сторін СТВ (профспілок, роботодавців, держави), а також на розширення можливості участі інститутів громадянського суспільства в соціальноекономічному розвитку України та їі регіонів.

В сучасних українських умовах дієва інформаційно-комунікативна стратегія взаємодії суб’єктів СТВ має відповідати таким базовим вимогам:

1. базуватися на принципах соціального діалогу і соціальної відповідальності та всебічно сприяти реалізації цих принципів [17];

2. враховувати реальний стан та динаміку СТВ, найважливіші проблеми з найбільшим конфліктогенним потенціалом, приділяти саме цим проблемам найбільшу увагу та забезпечувати прозору та зрозумілу комунікацію суб’єктів щодо їхнього вирішення;

3. бути орієнтованою на загальносвітові тренди розвитку та функціонування економічних систем, зокрема - процеси цифровізації та становлення інформаційної економіки;

4. максимально використовувати найновіші види та форми комунікації, які стають доступними завдяки розвитку сучасних інформаційно-комунікативних технологій, в тому числі - соціальні медіа (насамперед - соціальні мережі);

5. мати дієві механізми оперативного зворотного зв’язку між усіма сторонами комунікації - суб'єктами СТВ, адже наявність таких механізмів $є$ необхідною умовою забезпечення ефективної комунікації.

Цілями такої стратегії насамперед мають бути відновлення взаємодовіри суб’єктів СТВ та створення каналів ефективної та прозорої комунікації між ними. Найбільш перспективним типом комунікативної стратегії взаємодії суб’єктів СТВ, зважаючи на складну та сповнену гострих протиріч ситуацію та наявність значного протестного потенціалу в цій сфері, $є$ конвенціональна комунікативна стратегія, сутність якої полягає в забезпеченні комунікації між різними суб'єктами крізь цілу низку консенсусів конвенцію, тобто змістовний договір щодо базових принципів взаємодії, яких мають дотримуватись всі учасники взаємодії [28].

Широке залучення інститутів громадянського суспільства (ІГС) як з боку роботодавців, профспілок, малого та середнього бізнесу, так і інших громадських організацій та об’єднань соціально-економічної спрямованості потребує розширення платформи соціального діалогу до формату публічного партнерства. Перехід на розширену платформу соціального діалогу потребує досягнення двох ключових балансів:

1. збалансування соціальної відповідальності соціальних партнерів (бізнесу та найманих працівників) з їх впливом на прийняття рішень щодо державної соціально-трудової, соціально-економічної та екологічної політики;

2. збалансування «інтересів представницьких організацій роботодавців та найманих працівників (3 урахуванням соціально-економічної ролі кожного в залежності від сегменту бізнесу (за розміром) 3 відповідним представництвом інтересів в системі соціального діалогу)» [22]. На сьогодні вплив 
різних сегментів бізнесу на державну політику $є$ неспівставним. Якщо великий бізнес ефективно вирішує свої проблеми кулуарно, то малий та середній бізнеси, які в цивілізованих країнах є основою економічного зростання, соціальної відповідальності, зайнятості, а, отже, і сталого розвитку, по суті, позбавлені реальних важелів впливу на соціально-економічну політику держави.

Очевидно, що реалізація відповідної комунікативної стратегії є вкрай важливим кроком щодо подолання соціальних та соціально-психологічних перешкод активізації конструктивної взаємодії суб'єктів СТВ адже без відновлення прозорої комунікації вирішення всіх інших проблем $є$ неможливим [4]. В той же час існує велика кількість інших аспектів та механізмів, необхідних для такої взаємодії: нормативноправових, організаційно-управлінських, інституційних, кадрових тощо. Держава, влада, бізнесструктури і громадянське суспільство мають об’єднати зусилля для реалізації цілей модернізації економіки та соціально-трудової сфери України.

\section{вИСНОВки}

Система відносин у трудовій сфері, що діє на сьогодні, не є сприятливою для плідної конструктивної взаємодії між сторонами СТВ, що різко обмежує можливості здійснення соціального діалогу, досягнення соціальної злагоди, консолідації соціальних суб’єктів (держави, влади, громадянського суспільства, територіальних громад, бізнесу тощо) для вирішення найгостріших суспільних та соціально-економічних проблем.

В контексті запропонованої концептуальної тріади «довіра - поінформованість - вмотивованість» необхідними умовами активізації конструктивної взаємодії суб’єктів СТВ є підвищення взаємної довіри, ефективної системи комунікації, а також наявність їхньої волі до узгодження інтересів і готовність до діалогу та компромісу. Високий рівень довіри і по «вертикалі» (влада - громадськість), і по «горизонталі» (між соціальними групами) знижує рівень соціальної ентропії і сприяє соціальній згуртованості, забезпечує можливості для збалансування екологічних, соціальних та економічних інтересів завдяки покращенню координації (шляхом здійснення соціального діалогу).

На концептуальному рівні активізація конструктивної взаємодії суб’єктів СТВ має визначатися загальновизнаними концепціями соціальної відповідальності та соціального діалогу. Саме ці концептуальні підходи узагальнюють передовий світовий досвід суб’єктів СТВ, мають значний досвід практичної реалізації і відповідне методичне забезпечення та вже знайшли відображення у багатьох концептуальних та нормативно-правових документах, що регулюють сферу СТВ в Україні та визначають іï розвиток (хоча формування дієвих механізмів реалізації цих підходів в Україні наразі залишається відкритим питанням).

Аналіз практичної діяльності, спрямованої на модернізацію системи СТВ на основі принципів соціальної відповідальності та соціального діалогу виявив суттєвий дисбаланс: основна увага приділяється удосконаленню нормативно-правової бази та перенесенню західного досвіду (в тому числі і у вигляді соціального експериментування та різного роду пілотних проектів), при цьому фактично поза увагою залишаються базові чинники конструктивної взаємодії - довіра, поінформованість, вмотивованість. Діюча національна модель соціального діалогу не достатньо відповідає викликам часу та не виконує поставлені перед нею завдання. Актуальною залишається проблема недостатньої сформованості суб’єктності самих суб’єктів СТВ (профспілок, робітників, роботодавців, територіальних громад, відповідних державних органів) $з$ точки зору їхньої здатності повноцінно представляти колективні інтереси певних соціальних груп, так і з точки зору їхньої здатності здійснювати плідний цивілізований соціальний діалог для розв’язання найгостріших питань. Проблеми довіри та ефективної комунікації гостро стоять не тільки між самими суб’єктами, але і в їх внутрішньому середовищі, серед них самих.

Для успішної модернізації системи соціально-трудових відносин в Україні на засадах соціального діалогу та соціальної відповідальності, для активізації конструктивної взаємодії суб’єктів СТВ основним 
пріоритетом має стати налагодження розширеної інформаційно-комунікативної платформи соціального діалогу в трудовій сфері, що потребує переходу на оновлений формат комунікативної взаємодії суб’єтів соціально-трудових відносин, в основі якого лежить конвенціональна комунікативна стратегія.

\section{СПИСОК ЛІТЕРАТУРИ}

1. Antoniuk, V. Р. (2017). Світові тенденції у розвитку соціально-трудових відносин як виклику для України. In Zbirnyk tez dopovidei uchasnykiv mizhnarodnoi naukovo-praktychnoi Internet-konferentsii "Sotsialno-trudova sfera: suchasnyi stan, problemy ta stratehichni napriamy rozvytku”, 14-16 lystopada, 2017 r. (pp. 160-162). Kyiv: KNEU. Retrieved from http://ir.kneu.edu.ua/handle/2010/22994

2. Arseenko, A. Н. (Ed.) (2017). Рабочий класс современной Украины [Rabochyy klass sovremennoy Ukrayny] (318 p.). Kyiv: Instytut sotsyolohyy NAN Ukrayny. Retrieved from http://i-soc.com.ua/ua/news/rabochij-klass-sovremennoj-ukrainy-pod-red.-a.g.-arseenko.kiev-institut-sociologii-nan-ukrainy-2017.-318-s

3. Babych, T., \& Shynkarenko, Н. (2016). Місце і роль сторони роботодавців у формуванні інституту соціального діалогу в Україні [Mistse i rol storony robotodavtsiv u formuvanni instytutu sotsialnoho dialohu v Ukraini]. Viche, 11. Retrieved from http://veche.kiev.ua/ journal $/ 5242$

4. Blyzniuk, V. V. (Ed.) (2017). Модернізаџія соиіально-трудової сфери Донбасу: загрози та можливості [Modernizatsiia sotsialnotrudovoi sfery Donbasu: zahrozy ta mozhlyvosti] (136 p.). Kyiv: Instytut ekonomiky ta prohnozuvannia NAN Ukrainy. Retrieved from http://ief.org.ua/docs/sr/297.pdf

5. Bulieiev, I. P., Briukhovetska, N. Y., \& Bohutska, O. A. et al. (2016). Методи розвитку та забезпечення капіталізації промислових nідприємств в умовах інституиіональних змін [Metody rozvytku ta zabezpechennia kapitalizatsii promyslovykh pidpryiemstv $v$ umovakh instytutsionalnykh zmin] (312 p.). Kyiv: Instytut ekonomiky promyslovosti. Retrieved from http://iie.org.ua/monografiyi/metodi-rozvitkuta-zabezpechennya-kapitalizatsiyi-promislovih-pidpriyemstv-v-umovah-institutsionalnih-zmin-i-p-bulyeyev-n-yu-bryuhovetska-tain-2016-r/

6. Fond «Demokratychni initsiatyvy» imeni Ilka Kucheriva (2017). Громадська думка, грудень-2017: виборчі рейтинги і рейтинги довіри [Hromadska dumka, hruden-2017: vyborchi reitynhy i reitynhy doviry]. Retrieved from http://dif.org.ua/uploads/doc/11718337605a665adc 7b97d3.95892743.doc

7. Fond «Demokratychni initsiatyvy» imeni Ilka Kucheriva (2017). Опитування громадянської думки щзодо громадського залучення [Opytuvannia hromadianskoi dumky shchodo hromadskoho zaluchennia]. Retrieved from http://dif.org.ua/uploads/pdf/17873180355a2ea1 6f3ddcd8.59539501.pdf

8. Fond «Demokratychni initsiatyvy» imeni Ilka Kucheriva (2017). Соціальна напруженість та протестна активність: погляд соиіологів (круглий стіл, 22 вересня 2017 року) [Sotsialna napruzhenist ta protestna aktyvnist: pohliad sotsiolohiv (kruhlyi stil, 22 veresnia 2017 roku)]. Retrieved from https://dif.org.ua/uploads/pdf/119877939659c4e549b55712.17698919.pdf

9. Hetmantseva, N. (2016). Соціальне партнерство як спосіб інтеграції інтересів суб'єктів соціально-трудових відносин [Sotsialne partnerstvo yak sposib intehratsii interesiv subiektiv sotsialno-trudovykh vidnosyn]. Pidpryiemnytstvo, hospodarstvo i pravo, 3, 82-86. Retrieved from http://www.pgp-journal.kiev.ua/archive/2016/03/15.pdf

10. Kolot, A. М. (2018). Соціально-трудова сфера в координатах нової економіки: розширення можливостей та нові загрози [Sotsialno-trudova sfera v koordynatakh novoi ekonomiky: rozshyrennia mozhlyvostei ta novi zahrozy]. In Соціально-трудова сфера в умовах становлення нової економіки: глобальні виклики та домінанти розвитку (матеріали круглого столу, 15 травня 2018 р.) [Sotsialno-trudova sfera $v$ umovakh stanovlennia novoi ekonomiky: hlobalni vyklyky ta dominanty rozvytku (materialy kruhloho stolu, 15 travnia 2018 r.)] (pp. 7-15). Kyiv: KNEU. Retrieved from http://ir.kneu.edu.ua/bitstream/2010/25195/1/KS.pdf\#page=7\%3E

11. Kolot, A. M., Hrishnova, O. A., \& Herasymenko, O. O. et al. (2015). Соціальна відповідальність [Sotsialna vidpovidalnist] (519 p.). Kyiv: KNEU. Retrieved from http://ir.kneu.edu.ua/handle/2010/11583

12. Kuchabskyi, O. Н., \& Pohorielyi, S. S. (2013). Довіра до органів публічної влади як ключовий фактор ефективності системи державного управління [Dovira do orhaniv publichnoi vlady yak kliuchovyi faktor efektyvnosti systemy derzhavnoho upravlinnia]. Publichne upravlinnia: teoriia ta praktyka, 1, 103-108. Retrieved from http://nbuv.gov.ua/UJRN/Pubupr_2013_1_19

13. Ministry of Economic Development and Trade of Ukraine (2017). Цілі сталого розвитку: Україна (національна доповідь 2017) [Tsili staloho rozvytku: Ukraina (natsionalna dopovid 2017)] (176 p.). Retrieved from http://un.org.ua/images/SDGs_NationalReportUA_ Web_1.pdf

14. Natsionalnyi instytut stratehichnykh doslidzhen (2018). Аналітична доповідь до щорічного Послання Президента України до Верховної Ради України «Про внутрішнє та зовнішнє становище України в 2018 році» [Analitychna dopovid do shchorichnoho Poslannia Prezydenta Ukrainy do Verkhovnoi Rady Ukrainy «Pro vnutrishnie ta zovnishnie stanovyshche Ukrainy v 2018 rotsi»] (688 p.). Kyiv: NISD. Retrieved from http://www.niss.gov.ua/doslidzhennya/naukovi-vidannya/poslannya-prezidenta-ukraini/analitichna-dopovid-doschorichnogo

15. Novikova, O. F., \& Shastun, A. D. (2017). Управління людською свідомістю в сфері праці на засадах соціальної відповідальності [Upravlinnia liudskoiu svidomistiu v sferi pratsi na zasadakh sotsialnoi vidpovidalnosti]. Social and labour relations: theory and practice, 2, 100-107. Retrieved from http://nbuv.gov.ua/UJRN/stvttp_2017_2_9

16. Pankova, O. V., \& Shastun, A. D. (2017). Концептуальні засади розвитку трудової сфери України на принципах соціальної віповідальності в умовах модернізації. Ekonomichnyi visnyk Donbasu, 3(49), 164-172. Retrieved from http://dspace.nbuv.gov.ua/ handle/123456789/125395

17. Pankova, O., \& Kasperovych, О. (2018). Основні напрями та способи модернізації системи соціально-трудових відносин у промисловості на засадах соціальної відповідальності та соціального діалогу. Ukraina: aspekty pratsi, 3, 36-43. Retrieved from http://uap. in.ua/download/all/Vy-pusky-_2018_roku/UAP3_2018.pdf\#page=36\%22\%3E 
18. Parashchevin, М. А. (2016). Результати національних щорічних моніторингових опитувань 1992-2016 pp. [Rezultaty natsionalnykh shchorichnykh monitorynhovykh opytuvan 1992-2016 rr.]. Ukrainske suspilstvo: monitorynh sotsialnykh zmin, 3(17), 426-547. Retrieved from http://i-soc.com.ua/assets/files/monitoring/dodatki2016.pdf

19. Petrova, I. L., \& Blyznyuk, V. V. (Ed.) (2016). Розвиток соціально-трудової сфери України: теорія, практика, перспективи [Rоzvуtок sotsialno-trudovoi sfery Ukrainy: teoriia, praktyka, perspektyvy] (326 p.). Kyiv: Instytut ekonomiky ta prohnozuvannia NAN Ukrainy. Retrieved from http://library.krok.edu.ua/ua/kategoriji/monografiji/476-rozvytok-sotsialnotrudovoi-sfery-ukrainy-teoriia-praktykaperspektyvy

20. Razumkov Centre (2019). Рівень довіри до суспільних інститутів та електоральні орієнтації громадян України [Rіvеп doviry do suspilnykh instytutiv ta elektoralni oriientatsii hromadian Ukrainy]. Retrieved from http://razumkov.org.ua/napriamky/sotsiologichnidoslidzhennia/riven-doviry-do-suspilnykh-instytutiv-ta-elektoralni-oriientatsii-gromadian-ukrainy

21. Robotodavets (2017). Дорожня карта: «Стратегія модернізації соиіального діалогу» [Dorozhnia karta: «Stratehiia modernizatsii sotsialnoho dialohu»]. Retrieved from https://robotodavets.org.ua/2017/11/09/dorozhnya-karta-strategiya-modernizatsiyi-sotsialnogodialogu.html

22. Robotodavets (2019). Проблеми та перспективи модернізації соціального діалогу та публічних комунікацій задля успішних реборм [Problemy ta perspektyvy modernizatsii sotsialnoho dialohu ta publichnykh komunikatsii zadlia uspishnykh reform]. Retrieved from https:// robotodavets.org.ua/2019/02/28/problemy-ta-perspektyvy-modernizatsiyi-sotsialnogo-dialogu-ta-publichnyh-komunikatsij-zadlyauspishnyh-reform.html

23. Semykina, M. V., \& Beliak, T. О. (2018). Корпоративна культура в системі соціально-трудових відносин [Когрогаtyvпа kultura v systemi sotsialno-trudovykh vidnosyn] (248 p.). Kropyvnytskyi: KOD. Retrieved from http://dspace.kntu.kr.ua/jspui/ handle/123456789/7936

24. Shulha, M. О. (Ed.) (2017). Стан сучасного українського суспільства: цивілізаційний вимір [Stan suchasnoho ukrainskoho suspilstva: tsyvilizatsiinyi vymir] (198 p.). Kyiv: Instytut sotsiolohii NAN Ukrainy. Retrieved from https://i-soc.com.ua/ua/edition/books/stansuchasnogo-ukrainskogo-suspilstva

25. The Verkhovna Rada of Ukraine (2010). Закон України «Про соціальний діалог в Україні» [Zakon Ukrainy «Pro sotsialnyi dialoh v Ukraini»]. Retrieved from https://zakon3.rada.gov.ua/laws/show/2862-17

26. UNDP Ukraine (2018). Перетворення нашого світу: порядок денниц у сфері сталого розвитку до 2030 року [Peretvorennia паshoho cvitu: poriadok dennyi u sferi staloho rozvytku do 2030 roku]. Retrieved from http://www.ua.undp.org/content/ukraine/uk/home/library/ sustainable-development-report/the-2030-agenda-for-sustainable-development.html

27. Vorona, V. M., \& Shulha, M. О. (Ed.) (2018). Українське суспільство: моніторинг соціальних змін (1992-2018) [Ukrainske suspilstvo: monitorynh sotsialnykh zmin (1992-2018)]. Retrieved from https://i-soc.com.ua/ua/institute/offers

28. Zarytska, I. P. (2014). Категорія «Конвенціональна комунікативна стратегія» в контексті реалізації функцій державного управління. Naukovi pratsi [Chornomorskoho derzhavnoho universytetu imeni Petra Mohyly kompleksu "Kyievo-Mohylianska akademiia”]. Seriia: Derzhavne upravlinnia, 242(230), 56-61. Retrieved from http://nbuv.gov.ua/UJRN/Npchdu_2014_242_230_12 